\title{
Voorbeelde van die ontwikkeling van geloofsgemeenskappe in verskillende tekste en kontekste: Vanaf die Ou Testament en die Nuwe Testament tot vandag
}

\begin{tabular}{|c|c|}
\hline \multicolumn{2}{|c|}{$\begin{array}{l}\text { Authors: } \\
\text { Ananda Geyser-Fouche }{ }^{1} \bullet \\
\text { Carli Fourie }^{1} \mathbb{0}\end{array}$} \\
\hline \multicolumn{2}{|c|}{$\begin{array}{l}\text { Affiliation: } \\
\text { 'Department of Old } \\
\text { Testament Studies, Facu } \\
\text { Theology and Religion, } \\
\text { University of Pretoria, } \\
\text { South Africa }\end{array}$} \\
\hline \multicolumn{2}{|c|}{$\begin{array}{l}\text { Research Project Details: } \\
\text { Project Leader: A. Geyser- } \\
\text { Fouchè } \\
\text { Project Number: } 1258230\end{array}$} \\
\hline \multicolumn{2}{|c|}{$\begin{array}{l}\text { Description: } \\
\text { This research is part of the } \\
\text { project, 'Second Temple } \\
\text { Literature and Qumran', } \\
\text { directed by Dr Ananda } \\
\text { Geyser-Fouchè of the } \\
\text { Department Old Testament } \\
\text { Studies, Faculty of Theology, } \\
\text { University of Pretoria. }\end{array}$} \\
\hline \multicolumn{2}{|c|}{$\begin{array}{l}\text { Corresponding author: } \\
\text { Ananda Geyser-Fouchè, } \\
\text { ananda.geyser-fouche@up. } \\
\text { ac.za }\end{array}$} \\
\hline \multicolumn{2}{|c|}{$\begin{array}{l}\text { Received: } 15 \text { Aug. } 2018 \\
\text { Accepted: } 05 \text { Sept. } 2018 \\
\text { Published: } 05 \text { Dec. } 2018\end{array}$} \\
\hline \multicolumn{2}{|c|}{$\begin{array}{l}\text { How to cite this article: } \\
\text { Geyser-Fouchè, A. \& Fourie, } \\
\text { C., 2018, 'Voorbeelde van die } \\
\text { ontwikkeling van } \\
\text { geloofsgemeenskappe in } \\
\text { verskillende tekste en } \\
\text { kontekste: Vanaf die Ou } \\
\text { Testament en die Nuwe } \\
\text { Testament tot vandag', HTS } \\
\text { Teologiese Studies/ } \\
\text { Theological Studies 74(4), } \\
\text { a5222. https://doi.org/ } \\
\text { 10.4102/hts.v74i4.5222 }\end{array}$} \\
\hline \multicolumn{2}{|l|}{ Read online: } \\
\hline 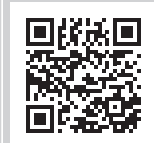 & $\begin{array}{l}\text { Scan this QR } \\
\text { code with your } \\
\text { smart phone or } \\
\text { mobile device } \\
\text { to read online. }\end{array}$ \\
\hline
\end{tabular}

In this study, the development of faith communities is investigated in different texts and contexts. The socio-religious understanding of various communities, from the time of the Old Testament, to today, has the potential to provide an understanding of ecclesiology and perceptions about what 'church' entails. In this study it is not suggested that there is one ideal faith community, nor can the approach of one faith community be adopted by another community. Every community exists within a certain socio-historical context and must be understood as functioning within that framework. Yet it is possible to learn from history by reinterpreting key elements in new contexts.

\section{Inleiding}

In hierdie studie word die ontwikkeling van geloofsgemeenskappe ondersoek. Die sosioreligieuse verstaan van verskeie gemeenskappe, vanaf die tyd van die Ou Testament, tot vandag, het die potensiaal om leidrade te gee vir die huidige verstaan van ekklesiologie en persepsies oor wat 'kerk' behels.

In 'n voorafgaande artikel ${ }^{1}$ is daar verwys na die ontstaan van geloofgemeenskappe, die eksklusiwiteit en inklusiwiteit ${ }^{2}$ wat in die totstandkoming van sulke gemeenskappe ter sprake is, asook die moontlikheid dat geloofsgemeenskappe in die Ou- en Nuwe Testament riglyne vir ekklesiologie kan bied. In hierdie studie word daar gefokus op die identiteit wat geloofsgemeenskappe op 'n sosio-religieuse vlak definieer.

Die unieke kontekste van die verskillende geloofsgemeenskappe wat in die studie in oënskou geneem word, is waardevol vir die verstaan van hedendaagse kerke. In die kerk handel God in verhoudings met die mens, wat beteken dat God op verskillende tye, in verskillendeomstandighede verskillend op mense se lewens inwerk (vgl. Breytenbach 1995:706-709; Geyser-Fouchè 2017:3, 7). Dit beteken dat dit wat vir een geloofsgemeenskap relevant en belangrik is, nie noodwendig vir 'n ander geloofsgemeenskap van belang is nie. Elke geloofsgemeenskap se konteks en behoeftes verskil. Dit is dus belangrik om elke unieke konteks in ag te neem. Brueggemann (1991:129) doen 'n beroep dat kerkmodelle deur spesifieke konteks(te) bepaal moet word en vir daardie spesifieke tyd en omstandighede toepaslik moet wees.

In die volgende afdelings sal daar gekyk word na hoe geloofsgemeenskappe in beide die Judaïsme en die Christendom ${ }^{3}$ ontwikkel het.

\section{Geloofsgemeenskappe in verskillende tekste en kontekste Judaïsme}

Binne die kader van Judaïsme het daar heelwat verskillende geloofsgemeenskappe bestaan, elk binne sy eie konteks en met sy eie vertrekpunt, ideologie en selfs teologie. Hacham (2005:5) noem dat sowel die ballingskap (hetsy of dit as 'n vrywillige of 'n gedwonge een opgeteken is) as die 1.Geyser-Fouché 2017 .

2.Eksklusiewe groeperingsgebruik: Levitikus 19:2 of Deuteronomium 23:1-8 as motivering, terwyl Jesaja 45:22; 56:1-8; Jeremia 12:16, en Amos 9:11-12 voorbeelde is van inklusiewe tekste in die Ou Testament.

3.Aangesien die Christendom voortspruit uit die Judaïsme en hulle paaie na ' $n$ baie ingewikkelde ontstaansproses geskei het, is dit nodig om in die gedeelte oor Judaïsme ook te verwys na die Christelike geloofsgemeenskappe en die reaksie van die Judaïsme daarop.

Copyright: @ 2018. The Authors. Licensee: AOSIS. This work is licensed under the Creative Commons Attribution License. 
verskillende historiese omstandighede, tot die onderskeie ideologieë en teologieë binne die Judaïsme ${ }^{4}$ gelei het.

Jaffee (2001) het die mondelinge tradisies en die vaslegging van die tekste in die Palestynse Judaïsme in die Laat Tweede Tempeltydperk en daarna (200 VAE-400 AE) ${ }^{5}$ bestudeer. Hy beklemtoon dat daar veral drie elemente is wat die inhoud van die tekste (hetsy mondeling of geskrewe) beïnvloed en bepaal het; die tekstuele aard van die tradisie of teks; die sosiale opset waarbinne die teks saamgestel, bewaar en oorgedra is; en die ideologiese sisteem waarbinne die teks(te) en hul sosiale opset binne die kultuur aangebied word (Jaffee 2001:9).

Gemeenskappe se unieke omstandighede en kontekste het bepaal wat hulle 'aanvaarde teks' is:

Under these conditions, the 'correct' text of a book was linked to the social boundaries of the community that preserved it. That community would harbor and reproduce its particular manuscript traditions. These would overlap in many ways with the traditions of other communities who happened to have preserved the same book, but there would also be important local differences. These might extend from differences in the spelling of particular words to variations in the sequence of particular passages and, in some cases, major disparities of content ... Only at the very end of the Second Temple period and more specifically in the decades leading up to the bar Kosiva rebellion of 132-135 [CE] does there seem to have been some desire to overcome the textual pluriformity of books regarded by most ancient Jews as part of the 'sacred writings'. (Jaffee 2001:19)

Die tempel in Jerusalem was die sentrum van skrifgeleerdes in die Tweede Tempeltydperk:

For most of the Second Temple period, the primary employer of various sorts of literary scribes was the Jerusalem Temple itself, which served as the political and economic, as well as the cultic, center of the country. Under the administration of a succession of High Priests from the time of the Persian restoration until its destruction in $70 \mathrm{CE}$, the operation of the Temple in its various roles depended upon its scribal infrastructure. (Jaffee 2001:20)

Jaffee (2001:22) beklemtoon dit dat die teks wat tans die geskrewe kanon van Judaïsme verteenwoordig, die vrug is van die kultiese gemeenskap in Jerusalem in die tyd van die Tweede Tempel.

Die sosio-kulturele omstandighede was derhalwe bepalend vir 'n geloofsgemeenskap, en 'n groep se geloofspraktyke kan nie bestudeer word sonder om dit in ag te neem nie. Uiteindelik bepaal die sosio-kulturele omstandighede die wese van die religieuse gemeenskap.

'n Dominante kenmerk van die Joodse lewe in Palestina in die Tweede tempelperiode was die invloed van die groepe wat van die Joodse gemeenskap weggebreek het. In hierdie groepe was die Fariseërs, Sadduseërs, Esseners en diegene wat in Qumran gewoon het (Baumgarten 1997:1).

4.Sien Baumgarten (1997) vir $n$ ' bespreking van die verskillende wegbreekgroepe (sektes) wat veral in die Makkabese tydperk ontstaan het.

5.Afrikaans vir BCE, is VAE (voor algemene era), en vir $C E, A E$ (algemene era).

\section{Diaspora}

Die fokus van die Jode in die diaspora het verskuif met betrekking tot waar JHWH teenwoordig sou wees. Alhoewel hulle die Jerusalem-tempel nog steeds beskou het as ' $n$ heilige en vername plek wat selfs by die nie-Joodse konings hoë aansien geniet het, is dit duidelik uit literatuur dat die sentrale posisie van die tempel afgeneem het en dat daar 'n poging was om 'n plaasvervanger daarvoor te kry (Hacham 2005:5; sien ook Gafni 1997).

Hacham (2005:7) verwys na 2 Makkabeërs, en noem dat die tempel in Jerusalem wel vir die Jode in die diaspora belangrik was, maar dat dit nie meer die fokuspunt van hulle godsdienstige wêreld was nie. Hulle geloof het JHWH eerder in die hemel as op 'n enkele en beperkte plek op aarde geplaas. Hacham (2005) verklaar dit soos volg:

... [T] he Diaspora Jews, who are distanced from it, could not accept the idea of God being present in a place other than among themselves. A religious person seeks his God, and if God is not with him, he is rendered religiously inferior and dependent upon other people and other places for his relationship with the divine. (pp. 7-8)

Volgens die werke van Philo ('n Jood in die diaspora) was daar meer as een moontlike verstaan van waar die tempel is: die wêreld kan as 'n tempel gesien word (Spec. 1.66); die tempel kan in 'n mens se hart wees (Somn. 1.149); die tempel kan ook in die midde van 'n geloofsgemeenskap gevind word [Sobr. 66]); en dan word daar ook verwys na die Jerusalem-tempel as die konkrete bewys van die allesomvattende teenwoordigheid van God (Spec 1.66-67) (vgl Hacham 2005:8).

Geskrifte soos 3 Makkabeërs maak dit duidelik dat die teenwoordigheid van JHWH, vir die Joodse diaspora baie eerder by sy mense as in die tempel te vind was. ${ }^{6}$ Die tempel is vervang deur die groep mense wat uitgebeeld word as God se uitverkorenes. Dit verklaar moontlik ook hoekom taalgebruik wat met die tempel geassosieer word, nie in die geskrifte van hierdie groeperinge gevind word nie. Dit is ook opvallend dat dié Jode baie meer aanklank by die Griekse vertalings van die Torah gevind en dit selfs verkies het.

Hacham (2005:9) verwys na 2 Makkabeërs 5:19.7 Hy sê die gedagte dat JHWH en die uitverkore geloofsgemeenskap belangriker is as die spesifieke heiligdom, of die ligging daarvan, het in die diaspora baie sterk na vore gekom en dat daar 'n duidelike parallel in die Rabbynse literatuur is:

We read in Sifre Numbers (161), 'Wherever they went into exile, the Divine Presence went with them' (כל מקום שגלו שכינה עמהם). Egypt, Babylon, Eilam and Edom are enumerated as places to which Israel went into exile with the divine presence accompanying them. Thus, the divine presence is not dependent on place; indeed, in times of exile it attaches itself to the people: wherever the people are, the divine presence is. (p. 9)

6.Sien 3 Makkabeërs $2: 2,6,9,13,14,16,18,21 ; 5: 13 ; 6: 1,3,5$

$9,18,29 ; 7: 10$.

7.It was not for the sake of the Place that the Lord chose the nation; rather, He chose the Place for the sake of the nation' (Hacham 2005:9). 
Die verhaal van Onias wys hoe die klem vanaf Jerusalem na Egipte verskuif het. Volgens hierdie verhaal het Onias die tempel juis in Egipte opgerig en verkies om dáár volgens die voorskrifte van die voorvaders te aanbid omdat Antiogus IV die tempel in Jerusalem verwoes het (vgl. Hacham 2005:9-16).

Die brief van Aristeas beeld die Griekse sentimente van die Jode in die diaspora duidelik uit. Daarvolgens is die Griekse vertaling van die Torah deur die twee en sewentig oudstes geheel en al akkuraat (Aris.310,314), tot so 'n mate dat al die belanghebbendes ingestem het dat daar niks daarby gevoeg moes word of weggeneem moes word nie (Aris.311). Die feit dat hierdie vertaling, in teenstelling met ander, suksesvol is, suggereer dat God die projek in 'n gunstige lig beskou het en dat die projek goddelike goedkeuring geniet het. Dit kom daarop neer dat die Egiptiese Jode nie meer die Hebreeuse weergawe van die Torah nodig gehad het om God se Woord te ken nie en gevolglik ook nie meer afhanklik was van Jerusalem as sentrum om die Torah te leer nie (Hacham 2005:11).

Die aanvaarding van die Griekse vertaling het gelei tot 'n verskuiwing van outoriteit vanaf die Tempel na die priesterlike leier se interpretasie van die Griekse geskrif. Die outeur van die brief van Aristeas het die tempel se sentrale posisie binne die halakhah nie ontken nie, maar het die behoefte vir onafhanklike toegang tot die Torah beklemtoon. (Hacham 2005:12). Die radikale religieuse verandering onder die groep kon die reaksie op 'n halakhah-dispuut wees. Dit kon uiteindelik die rede wees hoekom die sekte in ballingskap gegaan het, soos Hacham (2005:11) verduidelik: '... a group that went into exile because of a halakhic dispute must claim that its law is authoritative and deny any halakhic authority to the place and people of its origin'. Halakhah-dispute was redelik algemeen, dit het onder die Saduseërs en die Fariseërs ook bestaan, veral met betrekking tot elkeen se posisie binne die tempel in Jerusalem. In sekere Joods-Hellenistiese geskrifte word die outoriteit van die tempel in Jerusalem ondermyn (Hacham 2005:12).

Ballingskap is nie deur die Jode in die diaspora as inherent negatief beskou nie. Hierdie ingesteldheid kontrasteer met die Masoretiese Ou Testament wat die ballingskap nie net negatief nie, maar ook as die gevolg van die volk se afvalligheid uitgebeeld het. ${ }^{8}$ Die Jode in die diaspora het hulle situasie nie as negatief beskou nie, maar as 'n seën en vooruitgang (Hacham 2005:13).

Die Wysheid van Salomo bied 'n nuwe perspektief. Uitverkiesing word nou nie meer deur etnisiteit bepaal nie. Schaper (2013:301) verwys na hoe eksklusiwiteit in die Wysheid van Salomo nie meer handel oor Israeliet en nie-Israeliete nie, maar oor dié wat die vó $\mu$ o nie. In die Wysheid van Salomo word wysheid en die Torah nie teen mekaar afgespeel nie, maar die Torah gee leiding in 'n wêreld wat deur wysheid ontstaan het en bestuur word (Schaper 2013:301).

8.Sien onder meer Jeremia 25; Klaagliedere 1:5-6, 14, 18; Esegiel 12; Sagaria 7:8-14 2:17; Esra 9: 6-7; Nehemia 9:26-31.

\section{Yaḥad - Qumran}

In hierdie bespreking gaan daar meer spesifiek gekyk word na een van die sektes wat in die Tweede Tempeltydperk binne die Judaïsme ontstaan het, naamlik die Qumrangemeenskap (יחדי-Yahad).

Collins (2000a:5) se beskrywing van die raakpunte wat hierdie gemeenskap met beide Judaïsme en die Christendom het, ${ }^{9}$ toon waarom dit nodig is om dié spesifieke gemeenskap te bespreek.

In die Makkabese tyd het verskeie sektes ontstaan. Baumgarten (1997:7) bespreek die verskillende sektes en noem dat daar sekere kenmerke is wat alle sektes deel. Dit is kenmerke soos: vrywillige lidmaatskap; die feit dat 'n sekte ontstaan in protes teen die gebruike en geloof van die bestaande samelewing; en dan is daar die neiging van sektes om hulle in terme van reinheidsreëls en die uitverkiesing te definieer. Die Qumran-gemeenskap was so 'n sekte.

Vir hierdie bespreking is dit nodig om Hacham (2005:4) se opmerking in gedagte te hou: 'In one paper it is not possible to cover the entire range of details that comprise the mosaic of the Qumran sect's identity'. Die Qumran-gemeenskap is bekend as 'n sekte wat uit 'n apokaliptiese beweging ontwikkel het (vgl. García Martínez 2007:14). Tog is dit uit die geskrifte wat ontdek is, baie duidelik dat dit ook nie so eenvoudig is om van iets soos Qumran-Judaïsme te praat nie (vgl. Davies 2000:27-30).

Akademici se opinies oor hierdie gemeenskap het verander na mate meer geskrifte ontdek en bestudeer is. Collins (2000a:2) sê dat hulle wel nog oor sekere aspekte saamstem, soos byvoorbeeld die feit dat die gemeenskap 'n sekte was; dat hulle biblioteek bestaan het uit die Rolle (Scrolls) wat ontdek is; en dat hulle waarskynlik aan die Esseners verbind was. ${ }^{10}$ Tog is dit duidelik dat nie alle geskrifte wat ontdek is, die werke van die Qumran-gemeenskap was nie en dat die Esseners nie beperk tot Qumran was nie. García Martínez (2007:8) sê hulle was 'n groep wat van die Esseners weggebreek het (sien ook Jaffee 2001:30). Daar is wel 'n kernkorpus van die tekste, wat as sektaries beskou word. Dit is die geskrifte wat verwys na die 'Onderwyser' (Teacher of Righteousness), die gemeenskap en dié gemeenskap se eiesoortige motiewe en temas (vgl. Collins 2000a:2).

Die verandering in ideologie van die sektariërs van Qumran kan teruggevoer word na die wegbreek van deelname aan

9.Issues such as messianic expectation and judgment after death which became .Issues such as messianic expectation and judgment after death, which became
central in Christianity but less prominent in rabbinic Judaism, are also important in central in Christianity but less prominent in rabbinic Judaism, are also important in
the Scrolls. The Qumran community, like early Christianity, was informed by a lively the Scrolls. The Qumran community, like early Christianity, was informed by a lively
belief that the 'end of days' was at hand. We know of no comparable community in Judaism in the rabbinic period. At the same time, the religious ideals and ethica values of the Scrolls are in sharp contrast to the New Testament and closer to the world of the rabbis. In fact, the Scrolls are older than, and independent of, both Christianity and rabbinic Judaism. The catastrophic Jewish revolt against Rome, which incidentally brought about the destruction of Qumran, was to some degree the ashes from which both rabbinic Judaism and Christianity (as a predominantly Gentile religion) emerged. The Dead Sea sect was a product of the Hellenistic age Gentile religion) emerged. The Dead Sea sect was a product of the Hellenistic age and bears the imprint of that age in many ways. To appreciate it, we must do justice both to its continuity with Jewish tradition and to its distinctive innovations; both to the centrality of halakah and to the importance of eschatology; to its affinities both
with early Christianity and with rabbinic Judaism.

10.Sien Flint (2013:127-163) vir 'n volledige bespreking van teorieë oor die groepe waarmee die Qumran-gemeenskap geassosieer word, asook die ooreenkomste wat hierdie groep met die Esseners het. 
tempelaanbidding in Jerusalem. Hierdie skeiding het met die Makkabese opstand begin (Collins 2000a:3). Die tempel is destyds deur heidense aanbidding verontreinig. Dit het tot meningsverskille binne die oorspronklike Israel-groep gelei. Die Makkabeërs het die tempel in 164 VAE deur 'n oorwinning gesuiwer, maar dit was 'n kortstondige oorwinning. Gematigde Helleniste in die Joodse volk het beheer oor die tempelaanbidding verkry en dit het gelei tot skeuring binne die groep. Een groep het by tempelaanbidding gebly, terwyl die ander groep(e) hulle van hierdie vorm van aanbidding onttrek het (vgl. Schiffman 2010:81-82).

Met nuwe insigte uit tekste soos onder meer 4QMMT het dit duidelik geword dat die Qumran-groep se skeuring nie net aan die gebeure met betrekking tot aanbidding in die tempel toe te skryf kan word nie, maar definitief ook aan meningsverskille met betrekking tot die kalender en tegniese punte oor die Joodse wet (vgl. Collins 2000a:4).

Die lede van hierdie gemeenskap het duidelik nie die outoriteit van die Torah-instrukteurs van Jerusalem aanvaar nie. Hulle verwys na hierdie persone as דורשי הלקות ['soekers van gladde/vleiende dinge' /'seekers of smooth things'] ${ }^{11}$ en beskou Jerusalem-interpretasie(s) van die Torah as onwaar. In teenstelling met hulle is die 'Regverdige Onderwyser' (Righteous Teacher) die een wat die ware Torah geken het, en die Yahad op die weg van sy hart gelei het. ${ }^{12}$ Volgens die Pesher Habakuk praat hy uit God se mond (1QpHab 2:2-3); hy is ook die een aan wie God die vermoë gegee het om die woorde van die profete te interpreteer (8-9) en God het ook alles aan hom voorspel (9-10). Hy is dus gesien as die een wat goddelike inspirasie en openbaring ontvang het om die Qumran-gemeenskap te lei en hulle reg te leer.

Die Qumran-gemeenskap het hulleself as ballinge beskou, maar nie in die negatiewe sin (soos in die Masoretiese teks) nie. Hulle selfbeeld as die uitverkorenes van God ondersteun nie 'n negatiewe beeld nie (Hacham 2005:14). Hulle was nie in ballingskap as 'n vorm van straf nie, maar het vrywillig onttrek van die groep mense wat volgens hulle onregverdig was. Hulle het hulleself gedistansieer van die 'men of deceit' (sien onder meer 4Q397 14:21; 1QS 5:1-2; 1QS 8:11).

Die Yahad se fokus het verskuif vanaf die tempel in Jerusalem na 'n hemelse tempel en die gemeenskap het in wese die tempel vervang (vgl. Collins 2000b:12). Lede van die gemeenskap 'were ipso facto companions to the hosts of heaven and so living an angelic life, even on earth' (Collins 2000b:23-24). Volgens 1QS 11:5-8 en 1QH 11:19-23 ${ }^{14}$ het hierdie 11.Sien onder meer $1 \mathrm{QH}^{\mathrm{a}} \mathrm{X}(15 ; 32)$

12.Sien CD 1:11: ויקם מורה להם צדק להדריכם בדרך ולב en hy het 'n Onderwyser van Regverdigheid vir hulle laat verrys om hulle te rig volgens die weg van sy hart.

13. My eyes have gazed on that which is eternal, on wisdom concealed from men, on knowledge and wise design (hidden) from the sons of men; on a fountain of righteousness and on a storehouse of power, on a spring of glory (hidden) from the righteousness and on a storehouse of power, on a spring of glory (hidden) from the assembly of flesh. God has given them to His chosen ones as an everlasting possession, and has caused them to inherit the lot of the holy ones. He has joined their assembly to the Sons of Heaven to be a Council of the Community, a foundation of the Building of Holiness, an eternal Plantation throughout all ages to
come (Collins 2000b:24).

14.... because you have saved my life from the pit, and from Sheol and Abaddon you have lifted me up to an everlasting height, so that I can walk on a boundless plain gemeenskap 'n gerealiseerde eskatologie gehad (vgl. Collins 2000b:24).

Die eiesoortigheid van hierdie gemeenskap word raak beskryf deur Jaffee (2001):

What distinguished the Yahad from other Second Temple literary circles was one simple fact: while the scribal progenitors of such venerable texts as the Torah of Moses, the Enochic works, or Jubilees located the origins of their revelations in the distant past, the Yahad regarded itself as blessed to have such prophets in its very midst. Delivered with prophetic authority, the living traditions of the community were perceived not as supplements to prophetic books, but as divine disclosures themselves. As such, they were recorded in written texts, upon which alone all other forms of unwritten tradition would find their attenuated authority. (p. 38)

'n Belangrike religieuse element by die groepe van die diaspora wat die sentraliteit van die tempel afgewys het, was die vervanging van offers deur gebed. Die Qumran-gemeenskap was so'n groep. Gebed was meer prominent in die geskrifte van die Jode in die diaspora - eerder as in byvoorbeeld Palestynse geskrifte. Wanneer Philo die rol van die Hoëpriester beskryf, beklemtoon hy ook gebed bo offers (Philo Mos. 2.5; Spec. 1.97) (vgl. Hacham 2005:13). In 2 en 3 Makkabeërs is gebed die middelpunt van aanbidding. Die sinagoge in die diaspora word $\pi \rho \circ \sigma \varepsilon v ́ \chi \eta$ genoem, 'n huis van aanbidding, waar die

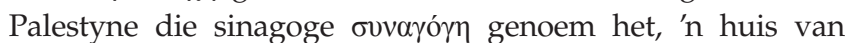
samekoms (vgl. Hacham 2005:13). Terme soos dié beklemtoon die voorkeure van sosio-religieuse groeperinge.

Die Jode in die diaspora en die Qumran-gemeenskap het verskil in hulle basiese houding teenoor die tempel, maar daar was tog ooreenkomste in sommige van hulle uitgangspunte. Die Qumran-gemeenskap het die tempel in Jerusalem beskou as 'n plek van sonde en verontreiniging, terwyl die Jode in die diaspora dit nog as 'n heilige plek beskou het (Hacham 2005:13). Tog was daar vir albei groepe 'n afname in die belangrikheid van die tempel; 'n soeke na plaasvervanging; en 'n poging om JHWH buite 'n spesifieke ligging in Jerusalem te plaas. Wanneer plaasvervanging voorgestel word, is die mense in die meeste gevalle die basis daarvan - gedefinieer as die uitverkore groep. Aan die ander kant, waar die Jode in die diaspora geneig was om weg te doen met taalgebruik wat met die tempel geassosieer is (plek, offers, versoening), gebruik die Qumran-geskrifte juis hierdie taal om na die Yahad te verwys as die spirituele vervanging van die tempel (vgl. Hacham 2005:9).

\section{Die Fariseërs}

Inligting oor die Qumran-gemeenskap word geskoei en verkry uit hul eie literêre nalatenskap, maar daarteenoor is die Fariseërs slegs bekend op grond van geskrifte wat deur eensydige en bevooroordeelde waarnemers saamgestel en neergeskryf is (vgl. Jaffee 2001:30). Jaffee (2001:9) is reg wanneer hy sê dat dit dus noodsaaklik is om ook te weet wat

\footnotetext{
.. The corrupt spirit you have purified from great sin so that he can take his place with the host of the holy ones, and can enter into communion with the congregation of the sons of heaven (Collins 2000b:24 [transl. Garcia Martinez])
} 
die belange van die relevante waarnemers was - hetsy neutraal of vyandig. Alleen wanneer die vertrekpunt(e) van die literêre getuies duidelik is, is dit moontlik om die data oor die Fariseërs te evalueer. Die Fariseërs word beskryf as persone vir wie nie net die geskrewe Torah van belang was nie, maar ook die eksegese en aanvulling wat bekend gestaan het as die 'mondelinge Torah' en wat deur die skrifgeleerdes vasgestel is (vgl. Jaffee 2001:39). Die Rabbynse konsep van tradisies wat die teks vertolk en interpreteer as 'n geldige openbaring van die mondelinge Torah, geniet van vroegs af steun. Jaffee (2001) stel dit so:

The point, to be precise, is that the sources of information on Pharisaism and its traditions of textual interpretation surely suggest a high degree of Pharisaic pride in possessing an ancient tradition of authoritative interpretations of the Torah's law in particular. (p. 39)

Bronne soos die kanonieke evangelies (wat meestal polemies teen die Fariseërs gerig is), Josephus se werke (Jaffee (2001:40) noem dat alhoewel baie historici sy werke as relevant beskou het, is dit duidelik dat sy vertolkings met relatiewe vryheid geskied het), en ander Rabbynse geskrifte (wat nie een veel aandag gewy het aan die historiese aspek van die Fariseërs nie), kan nie as objektiewe weergawes of historiese feite gesien word nie, maar verteenwoordig eerder literêre uitbeeldinge wat ideologies gemotiveer is (vgl. Jaffee 2001: 40-41).

\section{Sinagoge en kerk in die lig van Birkhat haMinim en die Bar Kochba-opstand}

Die vloei vanaf Judaïsme na Christendom asook die skeiding tussen hulle, blyk redelik vaag te wees. Die bestudering van sekere historiese aspekte soos die Birkhat haMinim, die bestaan en werking van die Yavneh, en die Bar Kochba-opstand kan aanduidings van hierdie oorloop en skeiding gee. Tog is daar soveel teenstrydige opinies oor wanneer wat gebeur het, asook oor wie verstaan word as die minim (sien onder andere Heemstra 2009; Joubert 1999; Kloppenborg 2011), dat daar nie 'n enkelvoudige verduideliking kan wees nie.

Joubert (1999:351) wys daarop dat die Birkhat haMinim (blessing against the heretics) nog altyd prominent was in besprekinge oor die skeiding tussen die kerk en die sinagoge, en die ontwikkeling van die Joodse Christendom.

Die meeste navorsing dui daarop dat die Birkhat haMinim ${ }^{15}$ nie teen Christene spesifiek gerig was nie, maar eerder op Joodse Christene en dat daar genoeg aanduiding is dat Christene in sinagoges, eerder verwelkom as vervloek is (vgl. Kloppenborg 2011:2).

Die Johannes-gemeenskap is as 'n groep uit die Joodse

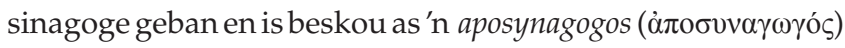
(Kloppenborg 2011:4). Kloppenborg (2011:13-14) bespreek 15.Sien Ehrlich and Langer (2005) vir' $n$ volledige bespreking van die vroegste tekste van die Birkat ha Minim. die moontlike verduidelikings vir die uitbanning en kom tot die gevolgtrekking, dat:

I suggest that what was at stake was deviant behaviour on the part of the Johannine Jesus-partisans: either failure to comply with the larger group's practices concerning Sabbath observance, or more likely, clique formation. (p. 14)

In hierdie evangelie word die verhouding tussen God en mens uitgedruk as vriendskaplik - die mens word nie as slawe uitgebeeld nie. Volgens Kloppenborg (2011) kon dit 'n

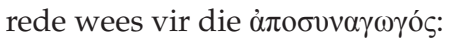

It is a fair conjecture, however, that if the Johannine sub-group had begun to express in its behaviour claims to special knowledge of the divine (and therefore a special relationship to the divine). This was at variance with dominant linguistic modes of expression and to engage in claims to 'love one another' and to constitute themselves as a fictive family (that is, a clique) within the synagogue, such behaviour would inevitably have put them into conflict with the archisynagogos and other authority structures in the synagogue. (p. 14)

Die Yavneh was 'n kommissie van Torah-geleerdes wat die riglyne vir ortodoksie opgestel het. Cohen (1984:29) beskryf die Yavneh as 'n groep wat nie uitgesluit het deur middel van die Birkhat haMinim nie, maar eerder: 'the goal was not the triumph over other sects but the elimination of the need for sectarianism itself'. Die Birkhat haMinim was 'n vervloeking op dié wat die Joodse tradisies en reëls gebreek het. Kloppenborg (2011:5) gee 'n opsomming van die argumente en moontlikhede wat deur geleerdes gegee word met betrekking tot die Birkhat haMinim en sluit dit af met 'n aanhaling van Boyarin:

Boyarin (2001) concludes: Once the evidence of and for a socalled 'blessing of the heretics' before the third century is removed from the picture, there is no warrant at all to assume an early Palestinian curse directed at any Christians. I am not claiming to know that there was no such thing, but rather that we cannot know at all, and that it is certain, therefore, that we cannot build upon such a weak foundation an edifice of Jewish-Christian parting of the ways. (p. 434)

Volgens Joubert (1993:355) het die Christelike verbanning eers werklik na die Bar Kochba-opstand plaasgevind. Urbach (1981:288) is ook van mening dat 'it was only after the Bar Kochba revolt, when the separation of Christians became final, that they were included amongst the "minim" for the first time'.

Die oorgang en/of skeiding tussen Judaïsme en Christendom is nie so maklik naspeurbaar nie. McGrath en Truex (2004:43) bespreek Alan Segal (1977) se navorsing oor die verhouding tussen Judaïsme en Christendom. Volgens Segal het die skeiding plaasgevind in die leer oor die 'twee hemelse kragte' wat deur die Joodse rabbi's gekritiseer is, maar McGrath and Truex (2004:71) meen dat hierdie polemisering eers heelwat later plaasgevind het en nie na die eerste eeu teruggevoer kan word nie. Verwysings in die Mishna sowel as die Tosefta kan eerder dui op Judaïstiese polemisering teen die Gnostisisme ('n tendens wat ook duidelik na vore kom in die Christendom se leringe) (vgl. McGrath \& Truex 2004:12). 
McGrath en Truex (2004:19) wys daarop dat Rabbi Akiba bekend was daarvoor dat hy Bar Kochba as die Messias geïdentifiseer het. Dit kan dalk 'n moontlike verklaring wees waarom daar eers werklik na die Bar Kochba-opstand 'n duidelike skeiding tussen Judaïsme en die Christendom op te merk was. ${ }^{16}$

Daar word heelwat oor die gebruik van die term 'kerk' vanuit die Grieks en Hebreeus beredeneer (Van Aarde 1990:254). Die woord $\sigma v v \alpha \gamma \omega \gamma \eta \dot{~ e n ~ غ ̇ \kappa \kappa \lambda \eta \sigma i ́ \alpha ~ v e r w y s ~ a l b e i ~ n a ~ t e r m e ~ w a t ~}$ voorkom in die Septuagint, wat verwys na die godsdienstige volk van Israel. Geyser-Fouchè (2017:2) wys daarop dat daar selde in die Nuwe Testament na die woord 'sinagoge' verwys word en let op dat die term 'sinagoge' na die sinagogegebou verwys en dat dié woord se noue verbintenis met die Joodse wet waarskynlik daartoe gelei het dat die term nie deur Christene gebruik is nie (vgl. ook Botma et al. 2000:743-777).

Van Aarde (1990:255; vgl. Botma, Koekemoer \& Van Aarde 2000), fokus op die roeping van die kerk en haar uniekheid as die fondasie wat op die Jesus-gebeure gebou is. Die ekklesia is meer as net die terminologiese verstaan.

\section{Christendom}

In hierdie gedeelte word die ontwikkeling van die Christendom bestudeer. Die feit dat dié godsdiens gespruit het uit die Judaïsme, noodsaak oorvleueling met die vorige bespreking. Die vroeë Christene toon dieselfde eienskappe as dié van die Joodse tradisie en daar is heelwat ooreenkomste tussen die Ou Testamentiese tradisielyn en die Nuwe Testament se aanbiddingsmetodes (vgl. Arnett 1951:126). Die rede vir dieselfde aanbiddingsmetodes is dat die vroeë Christene in Joodse families, asook Joodse tradisies grootgeword het. Arnett (1951:126) verwys na enkele teksvoorbeelde, naamlik, Lukas $24: 52-53^{17}$ en Handelinge 2:46. ${ }^{18}$ In effek het van die Joodse tempelpraktyke oorgespoel in die Christelike tradisie. Die Christene het nog steeds die Joodse Psalms gesing en dit is selfs tot op die hede nog in gebruik deur die Christelike tradisie. Die Sabbat en Joodse feeste is ook nog deur die Christene onderhou (vgl. Hand $13: 14 ; 30: 16)$

Die Qumran-gemeenskap het ooreenkomste met die Jesusbeweging. Scheffler (2016:4) argumenteer dat daar wel ooreenkomste tussen die Jesus-beweging en die Qumrangemeenskap is, maar steeds duidelike verskille. Hierdie deelwording het eers gekom na $68 \mathrm{AE}$, toe die Romeine die land ingeneem het. Scheffler (2016:4) bespreek vyf punte om die ooreenkomste en verskille te bepaal, naamlik: leierskap, sosiale rolle, interne hiërargie, lidmaatskap en etos.

16.Sien argumente hieroor in die vroëere bespreking van Joubert (1993) en Urbach (1981) se standpunte.

17. ${ }^{52} \mathrm{Hulle}$ het Hom aanbid en met groot blydskap na Jerusalem toe teruggegaan. ${ }^{53}$ Daar het hulle die hele tyd by die tempel gebly en God geprys. (NAV, Bybelgenootskap van Suid-Afrika, 1983)

$18 .{ }^{46} \mathrm{Hulle}$ het almal elke dag getrou by die tempel bymekaargekom, van huis tot huis die gemeenskaplike maaltyd gehou, hulle kos met blydskap en in alle eenvou geëet (NAV, Bybelgenootskap van Suid-Afrika, 1983).
Die leierskapmodel van die Qumran-gemeenskap en dié van Jesus vertoon ooreenkomste: 'Both preached penitence, humility, love and justice' (Scheffler 2016:4). Daar was wel verskille: Die Qumran-leier het gepreek dat armoede ideaal is en Jesus, aan die anderkant, het eerder geïdentifiseer met die armes.

Die Qumran-gemeenskap het op sosiale vlak baie streng reëls gehad en het hulle geloof nougeset in hulle lewe uitgeleef (Scheffler 2016:5). Die hiërargie in die Qumrangemeenskap het inisiasierituele gehad (sien 1QS 5:1-3), terwyl Jesus alle vorme van hiërargie afgewys het. Jesus het byvoorbeeld selfs sy dissipels se voete gewas (sien Joh 13:45,12-17). Die toelatingsvereistes tot die Qumran-gemeenskap was streng. Hulle het sekere mense uitgesluit (sien 1QSa 2:48). ${ }^{19}$ Jesus het sy lewe daaraan gewy om siek mense en gemarginaliseerdes te help en in te sluit. Die wet was vir beide die Qumran-gemeenskap (sien 1QS 5:7-9) en vir Jesus belangrik, maar Jesus se interpretasie het verskil (vgl. Matt 5:17-20 met Markus 2:28), aangesien Jesus die wet in terme van menslikheid geïnterpreteer het (Scheffler 2016:6).

Die Christendom het spoedig in die vroeë Christelike era versprei. Groot gebiede van landelike Palestina, soos Galilea en Samaria, was geneig tot ' $n$ absolute Joodse of Samaritaanse meerderheid en die invloed van die Christendom in dié streke was beperk en het eers heelwat later gekom as in die heidense nedersettings. Die Bisantynse ryk het byvoorbeeld 450 kerkgeboue in die vroeë Christelike era gehad (sien Bar 2003:405).

Argeologiese data gee ' $n$ aanduiding van hoe vinnig die verChristeliking plaasgevind het. Daar was 240 kerke wat die gemeenskap bedien het. Bar (2003) beskryf die oprig van 'n kerkgebou soos volg:

The erection of a church indicates that the local Christian community had reached an important milestone in its consolidation and points to an increase in the number of its followers as well as to the congregation's social power over other members of the rural community. (p. 407)

Alhoewel daar by Christene 'n behoefte was om soos die Jode in 'n gebou saam te kom, moet dit beklemtoon word dat daar wel verskille was in die doel en styl van die gebou. Bar (2003:420, 421) sê: 'Churches were built in an entirely different way from synagogues which were set up in settlements with a more religiously homogenous population'.

Die kerk het nie net 'n religieuse funksie gehad nie, maar ook 'n sosio-religieuse funksie. Die argeologiese data wys ook op verskeie kerkgeboue wat in die buitewyke van stede gebou is. Bar (2003:421) gee twee redes: Eerstens het daar verskeie pelgrims deur die stede beweeg, wat dan 'n buitewykse gemeenskapskerk die geleentheid gegun het om 'n pelgrim te bekeer; tweedens is dit 'n aanduiding van die Joodse dominansie in sekere stede. Die vinnige verspreiding van

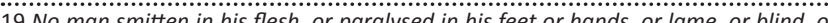
deaf, or dumb, or smitten in his flesh with a visible blemish; no old and tottery man
unable to stay still in the midst of the congregation; none of these shall come to hold office among the congregation of the men of renown ... (1QSa 2:4-8). 
kerkgeboue en die dringendheid om nie-Christene te bekeer, kan toegeskryf word aan die Christelike eskatologiese dringendheid. Stanley (1955) bespreek Handelinge en merk die volgende op:

In the first flush of their enthusiasm and by the phenomenal success which attended their early efforts to convert Israel, they naturally considered that the period of preparation for the Lord's advent would be a matter of comparatively little time. (p. 11)

Die Joodse dominansie het Christelike strukture na buite forseer. Die geloof in Jesus het ' $n$ baie sterk dryfveer in die harte van die gelowiges geword. Die vroeë Christene se sterk roepingsbewustheid was ook 'n aanduiding van die eskatologiese dringendheid wat deel van hulle verwysingsraamwerk was. Die Christendom was baie aantreklik vir nie-Jode omdat hulle by die Jesus-beweging kon aansluit, sonder om deel van die Joodse sinagoge te moes word. Jesus-volgelinge het heel aan die begin saam aan tafel gesit en om so 'n tafel hulleself begin organiseer (Botma et al. 2000:768). Sommige het die Joodse reinheidskodes onderhou en sommige het nie.

\section{Evangelies en historiese Jesus}

In die evangelies kom die kompleksiteit van konteks en die sosio-religieuse agtergrond ter sprake, wanneer daar oor Jesus-volgelinge en die historiese Jesus gepraat word (vgl. Van Aarde 2003:543-545). Dit is duidelik dat die Jesusbeweging een van vele bewegings in die omgewing van Jerusalem was (Mack 1988:88). ${ }^{20}$

Die eerste Jesus-volgelinge het saamgekom om 'n etenstafel om belangrike sake van gemeenskaplike belang te bespreek (Mack 1988:81). Dit is om die etenstafel waar die eerste gelowige Christene hulleself begin organiseer het. Dié spasie is ook gebruik om die Jesus-saak te beredeneer, asook of die Joodse rein/onrein-kodes as belangrik beskou behoort te word. Hieruit spruit onder meer die diversiteit binne die Christen-kultus, die besluit dat nie-Jode ook deel kon wees van die beweging, asook dat die Joodse reëls nie die status quo was nie (Mack 1988:107; vgl. Schmithals 1994:87-107, 225-226). Tog was daar heelwat Jesus-bewegings binne die Jodendom (Botma et al. 2000:768). De Villiers (1987:39) merk op dat die diverse en onderskeidende leefwyse van Jesusvolgelinge daartoe gelei het dat hierdie groepe die identiteit van 'Christene' gekry het (sien Hand 11:26).

Die Matteus-evangelie beeld die organisering van die kerk uit as belangrik vir die koms van die koninkryk en die kerugma van die apostoliese kerk is 'n voortsetting van Jesus se prediking oor die koninkryk (Stanley 1955:25). Die bergprediking het die tempel gedesentraliseer en was die begin van die prediking oor die koninkryk. Stanley (1955) wys daarop dat Handelinge op dieselfde wyse desentraliseer:

In the early years Jerusalem had seemed destined, with the Temple, to be the centre of Christianity. But Acts reveals a gradual movement away from the capital of Judaism ... Once the tide turned in the direction of the Gentiles, Jerusalem's task was 20.Mack (1988:84-96) onderskei ten minste vyf groepe. ended, and the focal point of Christianity was henceforth to be located elsewhere. (p. 20)

Handelinge (sien onder meer Hand 2:44-45; 4:32-35) plaas weer klem op die gemeenskap en kommunale besit:

$[I]$ ts author wishes to correlate the teaching of the apostles and the Eucharist with this 'communism' of the primitive Christians ... specified this relation of the koinonia to the Eucharist: the 'common life' was a necessary prerequisite for participation in the 'breaking of the bread'. (Stanley 1955:9)

Dit wil voorkom asof die kommunale lewe die vrugte was van vroeë Christelike teologiese denke wat uit die werking van die Heilige Gees spruit (vgl. Stanley 1955:9).

Deur middel van die verskillende evangelies, word dit duidelik dat die eerste volgelinge opmerklike sosio-religeuse kenmerke getoon het. In Matteus (16:13-19) word die sogenaamde stigtingsakte van die kerk aangetref. Dit dui op die prominente begin van die Jesus-beweging, deur Jesus wat self op die rots bou (let wel, nie deur die rots nie). Hieruit is dit duidelik dat Jesus self die kerk bou (nie mense of faksies nie) en dat dit Jesus se kerk tot sy eer is (wat nie deur mense of faksies besit, beheer of vernietig kan word nie) (vgl. Geyser 1960:19-21). Die enigste gronde waarop iemand uit die kerk gesluit kon word, was volharding in die sonde (Matt 18:1520). Insluiting word beklemtoon deur 'n sendingopdrag (Matt 10:1, 28:18; Joh 20:21-23); die kerk is bedoel vir die hele wêreld (Matt 24:14, 28:19); en is 'n eenheid (Joh 17:11, 20-23). In Markus 11:17 (as verwysing na Jes 56:7 wat polemies gerig is teen Deut 23:1-8), ${ }^{21}$ word beklemtoon dat die kerk ('my huis') 'n plek van gebed vir al die nasies moet wees.

Die historiese Jesus waarvan in die evangelies getuig word, is van groot waarde vir ons verstaan van kerkwees. Van Aarde (2003:550) wys daarop dat die Christendom dikwels gekritiseer word uitsluitlik op grond van Jesus se Joodsheid, maar dat daar nie grond daarvoor in die wese van die historiese Jesus is nie. Alhoewel Jesus van Nasaret etnies van Israelitiese afkoms was, het Hy in sy omgang op aarde alle grense oorgesteek, sonder om on-Joods te wees. Die verkondiging van 'geloof alleen' is te wyte aan sy leefwyse: 'The kerygma about living through faith alone historically finds its main support in a gender equitable, ethnically unbound, and culturally subversive Jesus' (Van Aarde 2003:550).

Jesus het krities omgegaan met sy Joodse tradisie, die Torah en die relevante geskrifte. Hy het hierdie tradisies en tekste teen die agtergrond van die liefdesgebod vertolk: 'Loving God and the neighbour constitutes not only the criterion, but the essence of Jesus' interpretation of his Jewish tradition' (vgl. Scheffler 2011:6).

\section{Paulus}

Botma en Van Aarde (1996:285-317) verwys na die diverse interpretasies met betrekking tot die Jesus-saak en dat Paulus se interpretasie veral geskoei is op sy verstaan van die 21.Sien Geyser-Fouché (2017:2-5) vir ‘n bespreking van die twee tekste. 
formule: 'in Christus': Dat die gelowige se deelname aan die Jesus-saak bepalend is en om deel daaraan te hê, beteken ook om aan die kerk te behoort en om kerk te wees.

Paulus se verstaan van die Jesus-saak is nie gebonde aan wetsonderhouding en etnisiteit nie, maar geskoei op liefde en aanvaarding van diversiteit (Gal 2; Rom 15:7-9, 13:8-10, Rom 14:1-3). Tog is dit duidelik dat sy breuk met die Judaïsme ook wrywing tussen hom en die Jerusalemgemeenskap veroorsaak het (vgl. Rom 15:31; 2 Kor 9:12-14; Asano 2005:98; Botma, Koekemoer \& Van Aarde 2000:773-774).

Paulus het binne diverse etniese groepe ${ }^{22}$ en deur interetniese verhoudings in die antieke wêreld opgetree. Indien die beskrywings van Paulus se reise in die boek Handelinge korrek is, is dit duidelik dat Paulus se verwysingsraamwerk met etniese diversiteit gevul was (Stanley 2013:183). Paulus se briewe getuig van 'n retoriese en kontekstuele sensitiwiteit.

Paulus se taalgebruik,, ${ }^{23}$ dui op 'in-groep-taalgebruik':

When we encounter the word 'Gentile' in a text, we can be certain that the author is writing from a Jewish in-group perspective that may or may not have been shared by those to whom the author is referring. (Stanley 2013:189)

Volgens Stanley (2013:189) het vreemdelinge nie na hulleself verwys as heidene (gentile) nie, behalwe wanneer hulle 'n sinagoge bygewoon het.

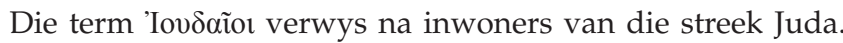
Hierdie etniese belange het behoue gebly, en selfs wanneer 'n groep mense weggetrek het, of in ballingskap weggevoer is, het hierdie groep mense nog steeds na hulleself verwys as

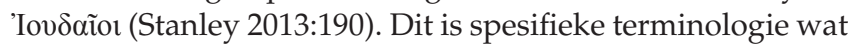
deur Paulus gebruik is om tot 'n sekere groep mense te spreek. Vreemdelinge of ander nasies van buite, sou nie noodwendig die taalgebruik verstaan het, as hulle nie in kontak was met die in-groep nie. Paulus het aan mense geskryf wat met etniese stereotipering gekonfronteer is en die terminologie wat hy gebruik het, is 'n poging om die stereotipering te wysig om insluitend te wees. Paulus se gebruik van ' $n$ verskeidenheid van terminologie is ' $n$ bewys dat sy tekste nie in 'n vakuum geskryf is nie, maar binne ' $n$ spesifieke konteks gerig word. Paulus het op hierdie manier die inter-etniese en/of etniese spanning binne die gemeentes hanteer (Stanley 2013:193, 194).

Paulus se sendingreise, briewe ${ }^{24}$ en missionêre werk gaan nie in detail bespreek word nie, ${ }^{25}$ die belangrikste aspekte van sy drie sendingreise is die manier waarop hy geloofsgemeenskappe ontwikkel het, hoe hy gemeentes met sy briewe bedien het en dat hy elke gemeente se eiesoortige konteks in ag geneem het.

22.Sien Stanley (2013:182-183) vir'n lys van die diverse groepe.

23.Sien ook Stanley (2013:189) vir 'n bespreking van die spesifieke terminologie in Paulus se taalgebruik.

24.Die sewe egte Pauliniese briewe is: 1 Tessalonisense; Galasiërs; 1 en 2 Korintiërs; Filippense; Filemon en Romeine.

25.Sien Van Eck and Van Aarde (2012) vir' $n$ volledige bespreking.
Volgens 1 Tessalonisense het Paulus in sy missionêre werk die evangelie onder die leiding van die Heilige Gees verkondig (sien 1 Tess 1:4-6; Van Aarde \& Van Eck 2012:25). Paulus se verkondiging in hierdie brief was gesetel in die trias (driedeling) geloof, liefde en hoop (van Aarde \&Van Eck 2012:25). Dit was vir Paulus ook die essensie van die Christelike bestaan. Paulus het die gemeente in Tessalonika onder teenkanting van die Judeërs gestig (Van Aarde \& Van Eck 2012:20). Hy meld ook dat die gemeentelede teenkanting van hulle volksgenote gekry het (sien 1 Tess 2:14-16; Van Aarde \& Van Eck 2012:20).

Dit wil voorkom asof die Galasiër-gemeente toevallig geëvangeliseer is. Paulus het in die omgewing siek geword tydens sy sendingreis en was vir 'n tyd in daardie omgewing (Van Aarde \& Van Eck 2012:31). Daar is geen sekerheid oor wie die hoorders van die gemeente was nie, behalwe dat dit Kelte of mense van die Romeinse provinsie in Galasië was. Die lede van die gemeente het van God afvallig geword. Paulus het in hulle afvalligheid beklemtoon dat die mens slegsdeurgeloofgered kan word enniedeurwetsonderhouding nie. Die sosiale omstandighede van die gemeente is nie duidelik nie (Van Aarde \& Van Eck 2012:30-36).

In 27 VAE het Korinte die hoofstad van Agaje geword, 'n hawestad en 'n handelsroete, bekend vir skeepsbou, nywerheid en algemene handel. As hawestad was Korinte gekenmerk as 'n stad van vele volkere van verskillende sosiale en morele stande, asook verskillende gelowe (Van Aarde \& Van Eck 2012:48). Die tweede brief van Korintiërs wys op nuwe probleme en dat hulle verhouding met Paulus versleg het (Van Aarde \& Van Eck 2012:74).

Die gemeente van Filippi is moontlik Paulus se eerste gemeente op die Europese vasteland. Filippi was 'n Romeinse kolonie en die streekshoofstad van Masedonië met verskillende gelowe, veral Griekse gelowe. Tóg blyk dit dat Paulus met hulle toegewyde geloof tevrede was. Dus kan daar afgelei word dat die gemeente floreer het (Van Aarde \& Van Eck 2012:87-88).

Die brief aan Filemon is gerig aan 'n individu en kan dus nie vir hierdie studie van belang wees nie. Romeine is 'n gemeente wat nie deur Paulus besoek is nie, alhoewel dit die eerste bron oor Jesus-volgelinge in Rome is. Akwila en Priscilla wat in Korinte aangekom het, was van die eerste volgelinge. Dit kan wees dat die gemeente spontaan deur Jesus-volgelinge ontstaan het. Die breedvoerige teologiese beskrywing in die brief kan ' $n$ aanduiding wees dat die gemeente nie met Paulus se teologie bekend was nie (Van Aarde \& Van Eck 2012:105-106).

\section{Histories vergelykende benadering: Die ontwikkeling van ekklesiologiese strukture vanaf die vroeë kerk tot vandag}

Voortspruitend uit die Judaïsme het die Jesus-bewegings ontstaan en daaruit die Christendom. Die Christendom in die Grieks-Romeinse wêreld was gesetel in die Bybelse teks as 
fondament. Kruger (2013:15) verwys soos volg daarna: 'At its core, early Christianity was a religion concerned with books'.

Soos wat daar al in Paulus se tyd verskillende groepering ontstaan het, het dit voortgegaan in die vroeë kerk. Elke groepering en/of geloofsgemeenskap het aan hulle bestaan 'n eie ontwerp gegee sodat daar verskeie ekklesiologiese strukture ontwikkel het. In dié studie sal daar drie tipes ekklesiologiese strukture bestudeer word. Dit is: 'n Institusionele benadering tot kerkwees; 'n transformerende benadering tot kerkwees; en ' $n$ nie-institusionele benadering tot kerkwees.

Institusionele benadering tot kerkwees: Die institusionele benadering tot kerkwees sluit in, volgens Dreyer (2011:3-4), die Rooms-Katolieke Kerk, die Ortodokse Kerk, en die Protestantisme. Die Rooms-Katolieke Kerk funksioneer volgens 'n hiërargiese struktuur (die Pous), soos uitgelê deur die Vaticanum I (1869-1871). Jesus vervul nog steeds die hoogste rol, as stigter van die kerk en die grondlegger van die kerklike reg en dissipline. Dreyer (2011:3) voer aan dit impliseer dat Kerk as instelling alreeds by Jesus begin het. Die klem op die goddelike oorsprong van die kerk in Vaticanum I, het tot 'n mate verskuif in die Vaticanum II, dat die kerk déúr Christus se handeling tot stand gekom het; dat Christus as Hoof van die kerk, die verantwoordelikheid aan die apostels en biskoppe gestel het (Flannery 1980:353). Die institusionalisering van die Rooms-Katolieke Kerk is duidelik deur die onderskeid tussen die amp en die leek (Dreyer 2011:3).

Die Ortodokse Kerk beklemtoon ook die instelling van kerkwees, soos Dreyer (2011:3) beskryf: 'Dié kerk is nog altyd beskou as die beskermer en bewaarder van die oorspronklike en suiwer leer (orthos doxa), soos deur die apostels aan ons oorgelewer'. Die Ortodokse Kerk is gesetel in onveranderlike dogma en tradisie. Dreyer (2011:3) beskryf die Ortodokse Kerk se teologie met die woord paradosis - wat vertaal kan word met 'dit wat oorgelewer word'. Die oorlewering kom vanuit die Bybel, besluite van die konsilies, die kerkvaders en die liturgie (Dreyer 2011:4). Die suiwer oorlewering van teologiese belange na die volgende geslag is van groot belang. Die instelling kry hier ook voorkeur deur die beskouing dat die Heilige Gees die leiding gee tot die instellings van die kerk, asook die hiërargiese struktuur en dat die biskoppe deur God aangestel is en God dus verteenwoordig (Kärkkäinen 2002:22).

Binne die Protestantisme het die instelling ook deur die eeue die voorkeur gekry, deur middel van die instandhouding van strukture en tradisies. Dreyer (2011:4) sê: 'Talle reformatoriese kerke, veral dié wat histories gesproke as volkskerke, landskerke of staatskerke ontstaan het, het bepaalde tradisies en gebruike wat die afgelope vyf eeue onveranderd gebly het'.

Transformerende benadering tot kerkwees: Die transformerende benadering tot kerkwees, behels vernuwing van strukture of rekonstruksie. Die vooruitgang van die kerk het al gekom vanuit die laat derde eeu na Christus en die begin van die vierde eeu. Dit het ontstaan uit die Christelike askese en monastiese ordes (Dreyer 2011:4). Lidmate (in plaas van ampsdraers) het gereageer op verswakte geloofswaardes en het geloof weer op 'n transformerende wyse versterk.

Die Middeleeue het heelwat hervormingsbewegings opgelewer. Diensbaarheid in die gemeenskap en kerk was aan die orde van die dag; daar was soveel soos 2000 kloosters in die 12de eeu na Christus. Onder leiding van pous Gregorius VII het die hervormingsbeweging in die Rooms-Katolieke Kerk begin (wat dan ook weer in 1414 met die Konsilie van Konstanz gestagneer het) (vgl. De Bruin 1965:58-59; Dreyer 2011:4). In die 14de eeu het die monastiese ordes begin verval, wat tot verdere hernuwings en die vestiging van nuwe ordes gelei het (Dreyer 2011:4).

Die vroeë kerkhervorming word gekenmerk deur die transformasie van die 16de eeu. Die bekendes in hierdie periode is Luther, Calvyn en Zwingli. Hulle aanvanklike bedoeling was nie om 'n nuwe kerk te stig nie, maar om Skriftuurlike beginsels te transformeer (Latourette 1964:701). Dreyer (2011:4) merk op: 'Dit was eers nadat die Regensburg Colloquium (1541) misluk het, dat die reformatore besef het dat die breuk met Rome finaal was'. Dit is tot nagedagtenis van die Reformasie dat die bekende spreuk vir transformerende kerkwees ontstaan het: ecclesia reformata, semper reformanda (Dreyer 2011:4).

Die hervormingsbewegings het egter vanaf die 16de eeu, vinnig die getrouheid aan hul naam verloor. Strukture het vasgewortel geraak, onder die invloed van die gereformeerde ortodoksie en die noue verbintenis tussen kerk en staat.

Die 20ste eeu het navorsing aangaande 'n transformerende benadering tot kerkwees opgelewer. Dit het verskyn in internasionale ekumeniese bewegings, byvoorbeeld. Nature and purpose of the Church (sien Faith \& Order 1998) en die opvolg dokument Nature and mission of the Church (sien Dreyer 2011:5; Faith \& Order 2005).

Die transformerende benadering tot kerkwees het gewildheid geniet in die postmoderne era in verskeie vakgebiede soos Gemeentebou (sien Nel 1994) en Praktiese Ekklesiologie (Dreyer 2011:5). Nel (1994:15) meen dat vernuwing in die kerk (in 'n Suid-Afrikaanse konteks) noodsaaklik is. Hy (1994:13) meen vernuwing berus op die Woord van God, wat setel in die kerk se roeping in die wêreld en die kerk se identiteit in Christus. Dreyer (2011:5) som dit op: 'Die gemeente moet transformeer om te word wat dit reeds in Christus is'. Dit is hierdie teorie in die onderskeie velde wat sukkel om in die praktiese leefwyse van die kerk tot uitvoering te kom.

Nie-institusionele benadering tot kerkwees: Die nieinstitusionele benadering tot kerkwees beoordeel tradisionele en institusionele vorms van kerkwees (vgl. Dreyer 2011:5). Hierdie kerkgemeenskappe funksioneer op 
die oorspronklike idees van die kerk, deur terug te kyk na Jesus en die eerste gelowiges. Dit is hiervolgens dat nuwe Christelike geloofsgemeenskappe op ' $n$ informele wyse gevestig word. Dreyer (2011:5) brei uit op Hirsch (2006:64) se 'emerging-missional' as post-institusioneel. Volgens Hirsch (2006:65) is ' $n$ nie-institusionele benadering tot kerkwees, in ooreenstemming met die Nuwe Testamentiese wyse van kerkwees. Viola en Barna (2008) verwys na die nieinstitusionele manier van kerkwees as 'n 'organic church', dit word soos volg beskryf:

A church that is born out of spiritual life instead of constructed by human institutions and held together by religious programmes. Organic churches a recharacterized by Spirit-led, open-participatory meetings and nonhierarchical leadership. (p. xix)

Die institusionele kerk se tradisionele gebruike van kerkgeboue, kleredrag, eredienste, prediking, offergawe en ampte het van die Nuwe Testament verskil (vgl. Viola en Barna 2008:xx). In die postmoderne era het daar heelwat missionale bewegings tot stand gekom. Die nie-institusionele benadering tot kerkwees is duidelik te sien in die geskiedenis. Voorbeelde van hierdie bewegings is die Anabaptiste beweging in die 16de eeu; die Morawiese beweging (Graaf von Zinzendorf) en Evangeliese beweging (John Wesley) in die 18de eeu; die Mukyokai-beweging in Japan (olv. Kanzo Uchimura) in die 19de eeu en die Shepherding-beweging in die 20ste eeu (Dreyer 2011:6; vgl Kärkkäinen 2002:163 ev.).

Dié studie wys ook op die bydrae van die 'Fresh Expressions'beweging wat 'n nie-institusionele benadering tot kerkwees is. Moynagh en Peabody (2016:4) beskryf kerk nie as 'n plek waarheen mense gaan nie, maar dat kerkwees in essensie is om kerk te wees. 'n Vars uitdrukking is ' $n$ missionale benadering tot kerkwees. Volgens hierdie benadering word daar vanaf die kerk as instelling uitgegaan na die omgewing om 'n behoeftebepaling te doen. Dit begin by 'n gemeenskap van gelowiges wat in die behoeftes van die gemeenskap voorsien deur na die gemeenskap se behoeftes te luister. Moynagh en Peabody (2016:19) het 'n vyfpunt-benadering tot 'Fresh expressions' ${ }^{26}$ Hierdie benadering funksioneer in klein groepe en die ampsdraer vorm nie meer die middelpunt nie. Dit is nie 'n nuwe idee van kerkwees nie, dit is in wese die Bybelse boodskap as elke gelowige se roeping (Viola \& Barna 2008:xx). Die benadering kan as missionaal getipeer word.

Missionale kerkwees is gefokus op die kerk se roeping in die wêreld (Van Aarde 2013:14). Die kerk is deel van die algemene kerk van Christus. Die missionale kerk is nie na binne gerig nie, maar na buite. Die missionale kerk spreek ook tot die behoeftes buite eie kringe en reik uit na persone wat nie deel is van die binnekring nie.

\section{Nederduitsch Hervormde Kerk van Afrika}

Die Nederduitsch Hervormde Kerk van Afrika (NHKA) het haar eie uitdagings. Hier word na die NHKA se 26.(1) "listening"; (2) "loving and serving"; (3) "building community"; (4) "explore discipleship'; (5) 'church taking shape'. uitdagings gekyk en bepaal of daar moontlike bedieningsmoontlikhede vanuit die algehele studie in die ontwikkeling van geloofsgemeenskappe is, wat tot hulp vir die NHKA kan wees.

Die NHKA was eens op 'n tyd 'n prominente kerk met baie lidmate, maar dit het verander. Volgens Dreyer (2016a:148) word daar in Suid-Afrika aangedui dat meer as die helfte van die bevolking gereeld eredienste bywoon, waar Suid-Afrika vierde op die wêreld se tabel is vir erediensbywoning. Die lidmaatgetalle binne die drie susterskerke (NHKA; NGK; ${ }^{27}$ $\mathrm{GKSA}^{28}$ ) in Suid-Afrika het ook drasties afgeneem. Dreyer (2016a:151) het in 'n tabel aangetoon dat daar in 1988 soveel soos 970366 lidmate in die NGK, 131466 in die NHKA en 78 417 in die GKSA was. Vanaf 1988 tot en met 2008 het die lidmaatgetalle geleidelik gedaal sodat die NGK slegs 880761 belydende lidmate gehad het, die NHKA slegs 10705 , en die GKSA 68842.

Die daling in lidmaattal het bepaalde langtermynimplikasies: die kerke se finansiële posisie verswak; sinodale poste word gerasionaliseer; teologiese opleiding word beduidend duur; voltydse predikante is onbekostigbaar en klein gemeentes sluit hul deure (Mead 1994:1-17, 128). Ungerer (2016:3) beskryf dit soos volg: '... organisasies sukkel om hulle werklike take uit te voer omdat strukture vir hulle so belangrik geword het en die pad van verandering na organisasievernuwing meestal morsig is'. Ekklesia kom 114 keer in die Nuwe Testament voor en elke keer verwys dit na 'n byeenkoms van mense (Ungerer 2016:4). Dit het in die moderne tyd die begrip van 'n kerkgebou gekry, wat dikwels gekritiseer word. Viola en Barna (2008) sê:

In the minds of the early Christians, the people - not the architecture, constituted a sacred place. The early Christians understood that they themselves - corporately - were the temple of God and the house of God. (p. iv)

'n Verwronge kerkmodel lei daartoe dat kerke kleiner word en uiteindelik sluit (Hirsch 2006:24).Volgens só 'n kerkmodel is die posisie van die predikant onaantasbaar. Die kerk behoort 'n nuwe manier van kerkwees te oorweeg, aangesien stagnasie nóg met die kerk nóg met die Bybel versoenbaar is (Heitink 2007:20-23).

Kerkwees kan nie in vandag se tyd verabsoluteer word nie, weens die uiteenlopende kerkmodelle. Die verskillende kerkmodelle en tradisies moet in gesprek tree om dieper insig in kerkmodelle te ontdek (Dreyer 2016a:101). Net so is daar verskeie voorbeelde van klein kerkgroeperings in die Ou Testament en huiskerke in die Nuwe Testament. Dit dui moontlik op 'n nuwe pad vorentoe. Volgens Hirsch (2006:24), sal die pastorale bedieningsmodel van die reformatoriese kerke drasties herbedink moet word.

Die NHKA reik na vernuwing, met die huidige kerkorde $\mathrm{e}^{29}$ wat'n missionale kerkmodel aanmoedig (NHKA 2016:77-81).

27.Nederduitsch Gereformeerde Kerk.

28.Gereformeerde Kerke van Suid-Afrika.

29.Goedgekeur op die 71ste AKV se Ordereël 7 en Ordinansie 7. 
Die uitdaging is om die rol van die predikant te verander sodat daar meer verantwoordelikheid toevertrou word aan elke gelowige en/of lidmaat. Die NHKA funksioneer nog grotendeels vanuit 'n pastorale bedieningsmodel. Dit behels dat die fokus moet verskuif vanaf ' $n$ pastorale bedieningspraktyk, na missionale kerkwees (nieinstitusionele benadering). Die implikasie is dat die predikant 'n onderrigrol aanneem, eerder as 'n pastorale rol. Dit kom daarop neer dat die lidmate die persone word wat die evangelie na die wêreld uitdra (soos met die 'fresh-expressions'benadering tot kerkwees). Dreyer (2009:4) voer aan dat verandering in die kerk nie enkelvoudig kan wees nie, maar dat dit 'n multidimensionele verandering moet wees. ${ }^{30}$ Ungerer (2016:6) voer ook aan dat daar holisties na die Hervormde Kerk gekyk moet word en haal vir Wright (2010:26) in dié verband aan: 'World evangelization requires the whole church to take the whole Gospel to the whole world'.

Die erkenning van verskille kan dalk 'n beginpunt wees. Van Aarde (2013) se voorstel begin by die dialektiese teologie:

Dialektiese teologie het raakpunte met etiese teologie. Dialektiese teologie erken verskille. Verskille kan langs mekaar leef en mekaar verryk. In hierdie denke is dit dus nie nodig om 'n middeweg te probeer vind nie. (bl. 6)

Dialektiese teologie aanvaar die diversiteit van tekste as 'n gegewe en lees tekste binne konteks met die wete dat elke outeur deur 'n spesifieke konteks gemotiveer is om die inhoud van die teks aan te pas by daardie spesifieke konteks. Van Aarde (2013:6) is 'n voorstander van die kontekstuele teologie, aangesien dit 'n verdieping van die dialektiese teologie is en omdat dié teologie besorg is oor almal wat onder sosiale onreg ly. Volgens Van Aarde (2013:6) vind die NHKA wel aansluiting by hierdie benadering met die stigting van kinderhuise, tehuise vir bejaardes, RATA (maatskaplike dienste) en die sustersvereniging (NHSV). ${ }^{31}$ Die NHKA sal voortdurend en vernuwend die manier van kerkwees moet ondersoek, om te bly transformeer en aan te pas by die voortdurend veranderende konteks. Dit is derhalwe op pad na 'n post-liberale teologie (sien Van Aarde 2013:3).

Modaliteite doen afbreuk aan die geloofsbelydenis se eenheid van die kerk, en kerkwees lyk nie oral eenders in die NHKA nie. Eenheid te midde van diversiteit is noodsaaklik en dit is die uitdaging waarvoor die kerk staan (Van Aarde 2013:4). Van Aarde (2013:4) bespreek die modaliteite wat voor die herskryf van die Kerkorde ${ }^{32}$ bestaan het vanweë die term 'volkskerk'. Hierdie term is geregverdig deur Bybelse verwysings en dit toon aan hoe ligtelik mense omgegaan het met hermeneutiek vir eie gewin (Oberholzer 2010:29). Die NHKA is in 'n tyd van heroriëntasie en Van Aarde (2013:11) stel 'n 'versoenende verskeidenheid' voor. 'Versoenende verskeidenheid' handel oor geloof en lewe, dit is hoe ' $n$ mens dink en leef (Van Aarde 2013:4). Hierdie beskouing het 30.Dreyer verwys na die agt verskillende vlakke van kerkwees van Heitink (2007). 31.NHSV = Nederduitsch Hervormde Sustersvereniging

32.Die Kerkorde is herskryf na die afloop van die 71ste Algemene Kerkvergadering gehou in 2016 waardering vir: die Bybel as 'n HeiligeSkrif; die geloofstradisie van die Protestantse kerk; die geloofsoortuigings van individuele gelowiges; die spiritualiteit van hedendaagse mense; asook die menswaardigheid van alle mense (Van Aarde 2013:4). 'Versoenend' dui op 'n voortgaande proses. Dit is nie 'versoenend' afgehandel nie. Die proses kan net voortgaan as mense bly bid en ontvanklik is vir die leiding van die Heilige Gees. Dit is die krag van God wat ons bymekaar hou, nie onsself nie (Van Aarde 2013:11).

Die vroeë Jesus-volgelinge was 'n voorbeeld van eenheid in verskeidenheid. Wanneer daar inter-etniese spanning tussen gemeentes ontstaan het, dan het Paulus dit aangepak. Die versoenende verskeidenheid moet aanhoudend gebeur en dit is op hierdie punt wat die NHKA leiding behoort te neem om die kerk met die wêreld te versoen.

Koffeman (2015:5) waarsku dat indien die kerk té veel klem op die menslike aksie as reformasie plaas, die kerk haar wese in die Heilige Gees gaan mis. Die kerk moet dus bewus wees van die noodsaak van eenheid versus verskeidenheid en konstant hervorm, maar terselfdertyd ook bewus wees wat sy in wese is (missio Dei). Oberholzer (1995:851) het uitgewys dat die kerk 'n kontemporêre benadering tot ekklesiologie vereis wat tot transformasie vir die NHKA kan lei en 'n eenvoudiger benadering tot kerkwees bied.

Die kerk moet krities omgaan met haar verstaan van kerkwees, want Loader (1987:56) waarsku alreeds in 1987 dat dit gevaarlik is om voor te hou dat die kerk die volheid van God se waarheid deurgrond. Die kerk sal 'n nuwe verstaan moet aanneem, wat getrou is aan die roeping van God. Dit is hoekom missionale ekklesiologie so aantreklik is. Hierin moet ook verstaan word dat dit nie net die roeping van die kerk is om 'n getuienis te wees vir die vergifnis van sonde deur Christus nie, maar dat die kerk ook 'n diens buite die kerk moet lewer om die wêreld 'n beter plek te maak (Beyers 2013:2). Van Aarde (2013:3) beskryf die teologiese etos van die NHKA as 'kritiese realisme', waarvolgens die kerk postliberaal in gesprek bly met die post-sekulêre en post-teïstiese tendens van die dag om 'n daadwerklike verskil te kan maak.

Dreyer (2013:3) stel voor dat die NHKA 'n paradigmaverskuiwing moet ondergaan, van die bekende Presbiteriaal-sinodale ekklesiologie, na 'n missionale ekklesiologie - die missio Dei. Missio Dei is wie die kerk in wese is. Dit is die kerk se roeping om deel te neem aan die missie van God in die wêreld (Dreyer 2013:4). Die problematiek met die Presbiteriaal-sinodale ekklesiologie is dat dit in wese pastoraal is, wat beteken dat die prediker/ dominee die middelpunt is, met ' $n$ kerkraad wat bestaan uit ouderlinge en diakens; sodoende word die individu se eie roeping en geloof nie aangeraak nie (Dreyer 2013:4). Missionale ekklesiologie is nie net ' $n$ algehele kerklike benadering nie, dit is ook individueel gerig. Dit is die verstaan van roeping soos wat dit duidelik in die gemeenskappe in die diaspora, die klein geloofsgemeenskappe en by Paulus te siene was. Dreyer (2013:5) verduidelik dit 
soos volg: 'Adaptive change is about changing the hearts and minds of individual congregants as well as the church collectively'.

Om die kerk se denke en hart te verander, sal gelowiges eienaarskap van hulle geloof moet neem. Die kerk moet kerk wees met integriteit. Die kerk moet aanhoudend transformeer en reformeer om kerk met integriteit te wil wees. Dit het praktiese implikasies. Die transformasie moet gepaard gaan met byderwetse taalgebruik. Die grootste uitdaging is vir lidmate om die missionale taal te verstaan. Taalgebruik sal ook konstant moet transformeer om aan te pas by die behoeftes van die omgewing en tot die egtheid van die missionale roeping (Dreyer 2016b:5). Die kerk word opgesom deur Dreyer (2016b):

The church, in Barth's words, is called to be church - not some charlatan organisation which recklessly endangers people's lives or falls into the trap of materialism. Living with integrity is not done for personal gain but the result of obedience to God and careful listening to what Jesus Christ taught us. (p. 7)

Die verandering is slegs moontlik as die sisteem migreer vanaf dominansie na 'n missionale verstaan van die kerk (Dreyer 2013:5).

\section{Sintese}

Dit is baie duidelik hoe daar vanaf die Judaïsme (hetsy die Diaspora, die Yahad, of die Rabbynse Judaïsme) klemverskuiwings plaasgevind het oor wat 'n geloofsgemeenskap is, waar JHWH teenwoordig is, asook hulle begrip van ' $n$ heiligdom. Hierdie klemverskuiwings word deur die sosio-kulturele omstandighede (konteks) van die spesifieke groepering bepaal.

Terwyl die Jode in die diaspora deur die regerende magte toegelaat is om hulle geloof uit te lewe, het die Yahad hulle godsdienstige reëls téén die wense van die regerende magte gevolg; tog het beide groepe geglo dat JHWH die voortgang en bestaan van die groep beskerm en verseker (Hacham 2005:19). Alhoewel daar min histories feitlike weergawes bestaan oor die Fariseërs is dit tog duidelik dat hulle baie sterk op die Torah gesteun het en ook hulle interpretasies daarvan as 'n openbaring en daarom geldig, beskou het. Dit is ook sigbaar in die latere ontwikkeling van die Mishna- en Rabbynse literatuur.

Dit is duidelik dat Judaïsme, wat rondom die tempel in Jerusalem gesentreerd was, tot die groepering in Jerusalem beperk was. Sowel die Jode in diaspora as dié van die Yahad het die voortbestaan van hulle sosio-religieuse praktyke nie aan 'n plek (bv. Jerusalem) gekoppel nie, maar eerder aan 'n groepering. In die latere ontwikkeling van Judaïsme soos wat mens in die Wysheid van Salomo vind, het dit duidelik geword dat etnisiteit nie meer die norm was vir sosio-religieuse groepering nie, maar eerder assosiasie en oortuiging - in dié geval die onderhouding van die vó $\mu \varsigma^{\prime}$.

Ooreenkomste tussen die $\mathrm{Ou}$ Testamentiese tradisielyn en die Nuwe Testament se aanbiddingsmetodes, asook die feit dat die Christendom voortvloei uit die Judaïsme, maak dit byna onmoontlik om te bepaal wanneer presies die skeiding plaasgevind het. Dit is wel duidelik dat die Christendom heelwat religieuse sowel as liturgiese elemente uit die Judaïsme behou het. Hierdie elemente het baie keer meer ooreenkomste met die wegbreekgroepe in die Judaïsme, soos die Qumran-gemeenskap en die Jode van die diaspora, as met die tempelgroepering in Jerusalem en die latere Rabbynse literatuur. Die Bar Kochba-opstand was waarskynlik die eerste werklike skeiding wat plaasgevind het tussen die Judaïsme en die Christendom.

Die lewe van die historiese Jesus en die verkondiging van die Sinoptiese evangelies het groot bydraes gelewer ten opsigte van die Christendom se kerkbegrip. Die historiese Jesus se uitreik na randfigure en inklusiewe benadering is van groot belang vir die ekklesiologie. Die eerste Christene het in klein groepies sonder enige hiërargiese ordes bymekaar gekom en die Evangelie verkondig. Paulus het met sy sendingreise en uitreik na diverse Christelike gemeentes heelwat klem gelê op die wegbreek van etnisiteit en die Judaïstiese gebruike. Hy het veral klem gelê op geloof alleen, aanvaarding van diversiteit, en was bekend vir sy kontekstuele sensitiwiteit.

Die ontwikkeling van geloofsgemeenskappe in die vroeë kerk het spoedig verstar in strukture, wat later soveel geïnstitusionaliseer is dat die spontane uitreik en omgee, wat die wese vorm van die historiese Jesus se verkondiging, vervaag het. Die Reformasie was 'n poging om terug te keer en telkens weer te hervorm (ecclesia reformata, semper reformanda), maar helaas het dit ook vasgeval in strukture en geloofsbelydenisse wat meer gesag gekry het as die Bybel self. Die nie-institusionele benadering tot kerkwees is ' $n$ hernude poging om terug te keer na die wese van kerkwees met ' $n$ missionele benadering, waar die konteks toegelaat word om 'n sê in kerkvorming te hê.

\section{Slotopmerkings}

Hierdie studie het die geskiedenis van die ontwikkeling van geloofsgemeenskappe bestudeer. Dit is baie duidelik dat daar nêrens ' $n$ wenresep vir die ideale geloofsgemeenskap is nie, nóg minder kan die een geloofsgemeenskap se benadering reglynig oorgeneem word deur 'n ander gemeenskap. Elke gemeenskap bestaan binne 'n bepaalde sosio-historiese konteks en moet binne daardie konteks funksioneer en verstaan word. Tóg is dit moontlik om uit die geskiedenis te leer deur belangrike elemente in nuwe kontekste te herinterpreteer.

Uit die gemeenskappe van die Joodse diaspora het dit duidelik geword dat hulle hul situasie nie as negatief beskou het nie. Hierdie gemeenskappe het duidelik verstaan dat transformasie, maar ook vervanging van die tradisionele instansie, die enigste uitweg is tot religieuse vernuwing indien nuwe sosio-historiese omstandighede dit verlang. Beyers (2013:9) verwys na die kerk se roeping en kultuur soos volg: 'Om kultuur te beskerm en te handhaaf is nie die kerk se roeping nie, maar om die kultuur waarbinne die 
kerk bestaan ten dienste van die verkondiging te benut, dit kan wel'.

Die oorspoel van Judaïsme in die Christelike tradisie maak die Judaïstiese tekste onmisbaar in die verstaan van die Christelike kerk. Uit die lewe van die historiese Jesus, die verkondiging van die Evangelies, asook die Pauliniese literatuur, is dit duidelik dat 'kerkwees in Christus' nie anders kan as om inklusief te wees en uit te reik nie. Kerkwees is om liefde te leef, dit is nie-etnies en kontekstueel sensitief.

Jesus het 'n radikale boodskap gehad en Jesus se beweging het die institusionalisering van geloof (gebonde aan 'n gebou soos in die Judaïsme) veroordeel (Scheffler 2016:9). Die ontwikkeling van die Kerk deur die eeue het baie eienskappe van hierdie ongewenste instelling geword en dit het daartoe gelei dat die kerk van haar roeping afgewyk het. Die instelling is nie ongewens nie, die praktyk van die roeping van geloof wat nie tot uitlewing gelei het nie, is wel ongewens. Scheffler (2016) se slotopmerking is treffend:

... [This] challenges modern Christianity in terms of assessing to what extent their values and existence can still be related to Jesus of Nazareth, whom they venerate and to whom they owe their existence. (p. 9)

In dié studie het daar verskeie raakpunte na vore gekom. Dit is duidelik dat konteks 'n wesenlike rol speel wanneer die kerk missionale migrasie oorweeg. Dit begin by geloof met integriteit wat liefdevol en kontekstueel sensitief is sodat die konteks toegelaat word om insprake te lewer. Daarna word 'n behoeftebepaling gedoen. As elke gelowige 'n passie ontwikkel vir die Bybelse boodskap, word die eenheid van gelowiges beklemtoon sodat die uiterlike kerklewe spontaan oorvloei in praktiese geloof, wat uitreik en behoeftes probeer vervul. Die kerk hoef nie vervang te word nie, kerkstrukture was vanaf die eerste gelowiges deel van die verstaan van Christelike kerk. Die belangrikste is dat die roeping nie in die struktuur verlore gaan nie. Die kerk moet voortdurend transformeer en gemeentelede in hulle taal en konteks ontmoet. Die belangrikste vraag is nie: Wie is ons as kerk nie? Maar veel eerder, elke gelowige in die kerk se vraag: Vir wie leef ek? Die voetewassimboliek, van die NHKA simboliseer elke lidmaat se roepingsantwoord: 'in Christus se voetspore'.

\section{Erkenning Mededingende belange}

Die outeurs verklaar dat hulle geen finansiële of persoonlike verbintenis met enige party wat hulle nadelig of voordelig kon beïnvloed het in die skryf van hierdie artikel nie.

\section{Outeursbydrae}

Die artikel in sy geheel is gesamentlik geskryf deur beide outeurs.

\section{Literatuurverwysings}

Arnett, L.E., 1951, 'The significance of the Old Testament in the New Testament church', Shane Quarterly 12(3), 0362-4609.
Asano, A., 2005, Community-identity construction in galatians, exegetical, socialanthropological and socio-historical studies, T\&T Clark International, London.

Bar, D., 2003, 'The Christianisation of rural Palestine during late antiquity', The Journal of Ecclesiastical History 54, 401-421. https://soi.org/10.1017/ S0022046903007309

Baumgarten, A.I., 1997, The flourishing of Jewish Sects in the Maccabean era: An interpretation (Supplements to the Journal for the Study of Judaism), Brill Academic Publishers, New York.

Beyers, J., 2013, 'Die roeping van die kerk', HTS Teologiese Studies/Theologic Studies 69(1), Art. \#1945, 1-10. https://doi.org/10.4102/hts.v69i1.1945

Botma, M.A., 1996, 'Die formule év Xpı๘Tũ as basis van die Pauliniese ekklesiologie', HTS Teologiese Studies/Theological Studies 52(2\&3), 285-317.

Botma, M.A., Koekemoer, J.A. \& Van Aarde, A.G., 2000, 'Onaanvaarbare verskeidenheid

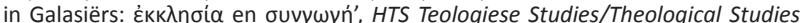
56(2\&3), 743-777. https://doi.org/10.4102/hts.v56i2/3.1772

Boyarin, D., 2001 'Justin Martyr Invents Judaism', Church History 70(3), 427-61. doi: $10.2307 / 3654497$

Breytenbach, A.P.B., 1995, 'Nadenke oor die kerkbegrip: Enkele perspektiewe op grond van die Deuteronomistiese geskiedenis', HTS Teologiese Studies 51(3), 702 711. http://dx.doi.org/10.4102/hts.v69i1.1982

Brueggemann, W., 1991, 'Rethinking church models through scripture', Theology today 48(2), 128-138, https://doi.org/10.1177/004057369104800202

Cohen, S.J.D., 1984, 'The significance of Yavneh: Pharisees, Rabbis, and the end of Jewish Sectarianism', Hebrew Uniton College Annual 55, 27-53.

Collins, J.J, 2000a, 'Introduction', in J.J. Collin \& R.A. Kugler (eds.), Religion in the dead sea scrolls, pp. 1-8, Eerdmans Publishing Co., Grand Rapids, MI.

Collins, J.J, 2000b, 'Powers in heaven: God, gods, and angels in the dead sea scrolls', in J.J. Collin \& R.A. Kugler (eds.), Religion in the dead sea scrolls, pp. 9-28, Eerdmans Publishing Co., Grand Rapids, MI.

Collins, J.J. \& Kugler, R.A., 2000, Religion in the dead sea scrolls, Eerdmans Publishing Co., Grand Rapids, MI.

Davies, P.R., 2000, 'The Judaism(s) of the Damascus document', in J.M. Baumgarten et al. (eds.), The Damascus document: A centennial of discovery, pp, 27-43, Brill, Leiden.

De Bruin, G.C., 1965, Handboek der kerkgeschiedenis, Deel II, Bert Bakker/Daamen D.V., Den Haag.

De Villiers, P., 1987, 'Die Apostelkonvent' (Handelinge 15), in C. Breytenbach (red.), Eenheid en konjlik: Eerste beslissinge in die geskiedenis van die Christendom, pp. 23-48, NG Kerkboekhandel, Pretoria.

Dreyer, T.F.J., 2009, '\#’n Kerk met karakter: Die perspektief van Gerben Heitink', HTS Teologiese Studies/Theological Studies 65(1), Art. \#315, 1-5. https://doi. org/10.4102/hts.v65i.315

Dreyer, W.A., 2011, 'Histories-vergelykende ekklesiologie - Op pad na 'n omvattende Praktiese Ekklesiologie', HTS Teologiese Studies/Theological Studies 67(3), Art. \#1083, 1-8. https://doi.org/10.4102/hts.v67i3.1083

Dreyer, W.A., 2013, 'Missional ecclesiology as basis for a new church order: A case study', HTS Teologiese Studies/Theological Studies 69(1), Art. \#1368, 1-5. https:// doi.org/10.4102/hts.v69i1.1368

Dreyer, W.A., 2016a, 'Historiese perspektief op kerkwees', HTS Teologiese Studies/ Theological Studies 72(5 suppl. 10), a4378. https://doi.org/10.4102/hts. v72i5.4378

Dreyer, W.A., 2016b, 'Church, mission and ethics. Being church with integrity', HTS Teologiese Studies/Theological Studies 72(1), a3163, 1-8. https:// doi.org/10.4102/hts.v72i1.3163

Ehrlich, U., \& Lenger, R., 2005, 'The earliest texts of the Birkat Haminim', Hebrew Union College Annual 76, 63-112.

Faith \& Order, 1998, The nature and purpose of the church, WCC, Geneva.

Faith \& Order, 2005, The nature and mission of the church, WCC, Geneva.

Flannery, A., 1980, Vatican Council II: The Concillar and Post Concillar Documents, Liturgical Press, Collegeville, PA.

Flint, P.W., 2013, The Dead Sea scrolls, Abingdon Press, Nashville, TN.

Gafni, I.M., 1997, Land, center and diaspora: Jewish construct in late antiquity, Sheffield Academic Press, Sheffield.

García Martínez, F., 2007, 'Qumran origins and early history: A Groningen hypothesis', in F. García Martínez \& E.J.C. Tigchelaar (eds.), Qumranica minora I. Qumran origins and apocalypticism, pp. 3-30, Brill, Leiden. '(Studies on the Texts of the Desert of Judah, vol LXIII.).

Geyser, A.S., 1960, 'Die Eerste Evangelie oor die eenheid van die Kerk as Christusgetuienis', in A.S. Geyser et al. (reds.), Vertraagde aksie, pp 12-23, Craft Press, Pretoria.

Geyser, A.S., Marais, B.J., Du Plessis, H., Keet, B.B., Van Selms, A. Redelinghuys, M., et al, 1960, Vertraagde aksie, Craft Press, Pretoria.

Geyser-Fouchè, A.B., 2017, 'Die kerk vanaf die Ou Testament en die Nuwe Testament tot vandag I: "Voortsetting, vervanging of transformasie?"\#' HTS Teologiese Studies/Theological Studies 73(1), a4570, 1-11. https://doi.org/10.4102/hts. v73i1.4570

Hacham, N., 2005, 'Exile and self-identity in the Qumran Sect and in Hellenistic Judaism', in E.G. Chazon \& B. Halpern-Amaru (eds.), New perspectives on Old Texts: Proceedings of the 10th International Symposium of the Orion Center for the study of the Dead Sea Scrolls and Associated Literature, 9-11 January, 2005, pp 3-21, Brill, Leiden. 
Heemstra, M., 2009, How Rome's Administration of the Fiscus Judaicus Accelerated the Parting of the Ways Between Judaism and Christianity, WUNT, vol. 2/277, Mohr Siebeck, Tübingen.

Heitink, G., 2007, Een kerk met karakter. Tijd voor heroriëntatie, Kok, Kampen.

Hirsch, A., 2006, The forgotten ways: Reactivating the missional church, Brazos, Grand Rapids, MI.

Jaffee, M.S., 2001, Torah in the mouth: Writing and oral tradition in Palestinian Judaism, 200 BCE-400 CE, pp. 1-239, Oxford University Press, New York.

Joubert, S.J., 1993,'A bone of contention in recent scholarship: The "Birkat Ha-Minim" and the separation of church and synagogue in the first century $A D^{\prime}, N e o$ Testamentica 27(2), 351-363.

Kärkkäinen, V.M., 2002, An introduction to ecclesiology: Ecumenical, historical and global perspectives, InterVarsity Press, Downers Grove, IL.

Koffeman, L.J., 2015, '\#“Ecclesia reformata semper reformanda" Church renewal from a Reformed perspective', HTS Teologiese Studies/Theological Studies 71(3), Art. \#2875, 1-5. https://doi.org/10.4102/hts.v71/3.2875

Kloppenborg, J.S., 2010, 'Disaffiliation in associations and the ároøuvapwyó of John', HTS Teologiese Studies/Theological Studies 67(1), Art. \#962, 1-16. https://doi. org/10.4102/hts.v67i1.962

Kruger, M.J., 2013, 'Manuscripts, scribes, and book production within early Christianity', in S.E. Porter \& A.W. Pitts (eds.), Christian origings and Greco-Roman culture, vol. 1, pp. 15-40, Brill, Leiden/ Boston.

Latourette, K.S., 1964, A history of Christianity, Eyre and Spottiswoode Ltd., London.

Loader, J.A., 1987, 'Tertium datur - Oor die etiese waarheidsbegrip', HTS Teologiese Studies/Theological Studies 43(1), 47-56.

Mack, B.L., 1988, A myth of innocence: Mark and christian origins, Fortress Press, Philadelphia, PA.

Mead, L.B., 1994, Transforming congregations of the future, Alban Institute, Washington, DC

McGrath, J.F. \& Truex, J., 2004, 'Two powers' and early Jewish and Christian Monotheism', Journal of Biblical Studies 4(1), 43-71.

Moynagh, M. \& Peabody, R., 2016, Refresh: A not-so-new guide to being church and doing life, Monarch Books, Oxford

Nel, M., 1994, Gemeentebou, Orion Uitgewers, Johannesburg.

Nederduitsch Hervormde Kerk van Afrika (NHKA), 2016, Kerkorde van die Nederduitsch Hervormde Kerk van Afrika, Nederduitsch Hervormde Kerk van Afrika Kerkargief Pretoria.

Oberholzer, J.P., 1995, 'Die kerk', HTS Teologiese Studies/Theological Studies 51(3) 851-857. https://doi.org/10.4102/hts.v51i3.1441

Oberholzer, J.P., 2010, “\#“Ekumeniese isolasie en interne stryd 1961-1970”, in Honderd Jaar Kerk en Teologiese Opleiding: 'n Kroniek van die Hervormde Kerk,
HTS Teologiese Studies/Theological Studies 66(3, Suppl. 9), Art. \#936, 1-21. https://doi.org/104102/hts.v66i3.936

Schaper, J., 2013, 'NOMOS and NOMOI in the Wisdom of Solomon', in B.U. Schipper \& D.A. Teeter (eds.), The reception of Torah in the wisdom literature of the second temple period, pp. 293-306, Brill, Leiden.

Scheffler, E., 2011, 'The (Markan and Matthean) Jesus' appropriation and criticism of the Torah: The question of divorce', HTS Teologiese Studies/Theological Studies 67(1), Art. \#1006, 1-6. https://doi.org/10.4102/hts.v67i1.1006

Scheffler, E., 2016, 'Putting Qumran, Jesus and his movement into relief', HTS Teologiese Studies/Theological Studies 72(4), Art. \#3479, 1-10. https://doi. org/10.4102/hts.v72i4.3479

Schiffman, L.H., 2010, Qumran and Jerusalem: Studies in the Dead Sea scrolls and the history of Judaism, Eerdmans, William B. Publishing Company, Grand Rapids, MI.

Schmithals, W. 1994. Theologiegeschichte des Urchristentums: Eine problemgeschichtliche Darstellung, Kohlhammer, Stuttgart.

Segal, A., 1977, Two powers in heaven. Early Rabbinic reports about Christianity and gnosticism, Brill, Leiden.

Stanley, C.D., 2013, 'The ethnic context of Paul's letters', in S.E. Porter \& A.W. Pitts (eds.), Christian origins and Hellenistic Judaism: Social and literary contexts for the New Testament, pp. 177-201, Brill, Leiden.

Stanley, D.M., 1955, 'Kingdom to Church: The structural development of Apostolic Christianity in the New Testament', Theological Studies 16(1), 0040-5639.

Ungerer, A., 2016, 'Hou Christus die Nederduitsch Hervormde Kerk van Afrika in stand?', HTS Teologiese Studies/Theological Studies 72(3), a3205. https://doi. org/10.4102/hts.v72i3.3205

Urbach, E.U., 1981, 'Self-isolation or self-affirmation in Judaism in the first rhree centuries: Theory and practice', in E.P. Sanders et al. (eds.), Jewish and Christian Self-Definition pp. 288-293, vol. 2, Fortress Press, Philadelphia, PA.

Viola, F. \& Barna, G., 2008, Pagan Christianity? Exploring the roots of our Church practices, Tyndale House Publishers, Carol Stream, IL.

Van Aarde, A.G., 1990, 'Die "heiligheid" van die kerk teen die agtergrond van die breuk kerk-sinagoge', In die Skriflig 24(3), 251-263. https://doi.org/10.4102/ids. v24i3.1352

Van Aarde, A.G., 2003, 'Does historical Jesus research have a future?', Verbum et Ecclesia Jrg 24(2), 533-556. https://doi.org/10.4102/ve.v24i2.325

Van Aarde, A.G., 2013, '\#'n Postliberale perspektief op 'n ekklesiologiese modaliteit as 'n ecclesiola in ecclesia - heroriëntasie in die Nederduitsch Hervormde Kerk van Afrika', HTS Teologiese Studies/Theological Studies 69(1), Art. \#2012, 1-14. https://doi.org/10.4102/hts.v69i1.2012

Van Aarde, A.G. \& van Eck, E., 2012, Die outentieke briewe van Paulus: Inleiding en teologie, NTW 451, Studiehandleiding, Universiteit van Pretoria, Pretori.

Wright, C.J.H., 2010, The mission of God's people, Zondervan, Grand Rapids, MI. 